\title{
From order to (dis)order in the land reform programme of Zimbabwe: was environmental sustainability retained?
}

\author{
E. Kori \\ Department of Geography and Geo-Information Sciences, \\ University of Venda, South Africa
}

\begin{abstract}
Land reforms have occurred throughout the world for different reasons including the need to change patterns of land ownership or land use. In Africa, such reforms aim to redress the discriminatory colonial land policies by providing the poor and disadvantaged with arable land. To be successful, land use options within a land reform programme should incorporate not only social and economic viability, but environmental sustainability as well. One of the vexing challenges facing policy makers is how to redistribute land and at the same time ensure productivity and ecological sustainability. Critics of the Fast Track Land Reform Programme (FTLRP) in Zimbabwe have often characterised this challenge as a remnant of the government's move from the orderly willing buyer willing seller to the 'disorderly' command driven approach. Using the Ecological Footprint accounting approach, this paper endeavours to determine whether the change from willing-buyer-willing-seller to FTLRP compromised the environmental sustainability of the resettled areas. Data were collected from both primary and secondary sources in Chirumanzu District, Midlands Province of Zimbabwe through household questionnaires and key informant interviews. Results reveal that despite the change in the land reform approach, there is a generally environmentally sustainable situation prevailing in both the orderly and the (dis)orderly FTLP resettled areas. Contrary to popular view, both areas produced an ecological reserve. Such results may lead one to conclude that although there was a major shift in the land reform approach, the orderliness was not lost hence environmental sustainability was retained.

Keywords: land use, ecological resources, resettlement, land reform.
\end{abstract}




\section{Introduction}

Zimbabwe is a predominantly rural country where access to productive land resources is essential for social and economic development. However, between 1893 and 1980, the colonial government passed segregatory legislation such as the Land Husbandry Act of 1930, which deprived the majority of the Africans of the right to own productive land. This divided the country into prime land for Europeans and largely infertile and inhospitable land as "Native Reserves" for Africans. The result was that 3 per cent of the population got entitlement to about 39 per cent of the national total arable land [1-3]. African economic and social development was, therefore, stunted. Thus, the new government implemented land reforms after independence from Britain in 1980 to address these anomalies. However, land reform in Zimbabwe has been piece-meal and reactive in approach [4] culminating in environmental sustainability challenges.

Land reforms aim to promote noble ideas central to human livelihoods. Musyoki [5] and Mohamed-Katerere [6] observe that to be successful, land use options within a land reform programme should incorporate not only social and economic viability, but environmental sustainability as well. Environmental sustainability issues are among a host of vantage points taken by Zimbabwe government critics when it abandoned the intensive package approach. The intensive package approach entailed the provision of adequate basic support services such as access roads, water, and sanitation facilities, dipping tanks, clinics, schools and rural service centres, before or as soon as settlers had occupied the redistributed land [7-9]. The associated comprehensive planning done before the settlers' relocation ostensibly guaranteed environmental sustainability.

The new approach adopted in 2000 entailed the relocation of settlers to new settlement areas before basic social services and infrastructure had been established [10]. It became known as The Fast Track Land Reform Programme (FTLRP). It was a radical and controversial exercise. Existing landowners were sometimes forcibly removed from their hitherto farms. Methods of land acquisition, beneficiary selection and resettlement support changed to a completely command-driven approach [11]. Beneficiaries occupied farms before any provision of basic infrastructure and Government officials followed at a later stage to "demarcate" the land [12]. Critics viewed this approach as retrogressive and a recipe for serious ramifications on, among others, the sustainability of the environment in resettled areas. As a result there is a host of publications condemning the land reform programme in Zimbabwe.

\section{Environment and land reform debate}

Different publications [4, 13-15] point to environmental sustainability challenges in resettlement areas in Zimbabwe. However, according to the Zanu (PF)'s National Congress Report [16] one of the objectives of the FTLRP was to reduce pressure on land and enhance environmental sustainability. The Land Reform Task Force [10] identifies the intention to "promote environmentally 
sustainable utilization of land”, as one of the objectives of the FTLR. Manjengwa [14] however, observes that there was some "environmental degradation occurring as a result of accelerated resettlement causing conflicts over natural resource use..." This is supported by Murombedzi's [15] observation that “...settlers are ....asset strippers, cutting down trees, hunting wild animals and exploiting other natural resources so as to open up new lands for agriculture, reduce competition and protect their livestock from predation, but also to source capital to invest in their new agriculture enterprise.” Furthermore, the Zimbabwe Environmental Research Organization (ZERO) [4] argues that the post-colonial era in Zimbabwe has been characterised by growing levels of environmental degradation and, to date, land reform has done little to improve the environmental sustainability of rural land use practices. Adopting the fast track approach was worsening the already bad environmental situation.

Clover and Eriksen [9] add that despite the stated intention of addressing some of the problems of overcrowding and inequality, land reform in Zimbabwe has paradoxically failed to address overcrowding and resource scarcity on marginal lands, but instead precipitated new ecological, social and economic challenges. ZERO [4] observes that the pace of environmental degradation has nowhere been quicker than in resettlement areas. Compounding the situation is that environmental sustainability is not mainstreamed in the land reform process [13].

Harts-Broekhuis and Huisman [17] point out that resettlement schemes have been implemented in some comparatively vulnerable and agro ecologically poorly endowed regions of the country. Serious environmental degradation tailed demographic and economic changes that have produced a semblance of communal areas in resettlement schemes [18, 19]. Estimates suggest that resettlement resulted in deforestation ranging between 100,000 and 320,000 hectares per year [20].

Gold panning along Zimbabwe's rivers also mushroomed since the beginning of the FTLRP. Panning takes place unsustainably and unsystematically, usually in riverbeds, banks and flood plains with no concern for the environment [14]. The concern is the ability of such a scenario to sustain the ecosystem services which humanity will always need for survival.

Most of the above arguments emanate from the belief that for a sustainable environmental situation to prevail, humanity should extract ecological resources from, and release waste to the environment in quantities that the biophysical environment has the capacity to supply and absorb, respectively. In this context, environmental sustainability is considered in terms of the natural resources available to support life (biocapacity) against what humanity is extracting (Ecological Footprint) from nature. That is the point of departure for this paper.

While many of the publications cited above cite obvious human activities ostensibly causing environmental degradation in resettled areas, none of them supports their views with a robust scientific study. Their main basis is that the FTLRP lacked planning. However, Chaumba et al. [21] contend that order was never lost and that the FTLRP was a planning mishap is media propaganda. It is the aim of this paper to present results of a scientifically robust and transparent 
calculation of the demands humanity places on the natural environment from a scientific study of the resettled areas of Chirumanzu District of Zimbabwe. This should reveal the environmental sustainability status obtaining after the implementation of the FTLRP. The adoption of a natural resource supply and consumption approach affords the accomplishment of this aim as presented in the following section.

\section{Methods}

It is possible to track the majority of the resources people consume and the wastes they produce. These resources consumed and the wastes generated can be measured in physical terms [22]. This paper considers environmental sustainability in terms of the natural resources available to support life against what humanity is extracting from, and returning as waste to, the ecosystem. This is done through tracking the regenerative capacity of an ecosystem in terms of natural resource flows using the Ecological Footprint (EF) tool. These resources and waste flows are measurable in terms of biologically productive areas necessary to maintain the flows

The EF accounts for exploitation of the environmental renewable resources and the assimilative capacity by a given population over specified time [23, 24]. $\mathrm{EF}$ is a measure of sustainability, and use of interest rather than capital. The system compares the demand on ecological services (EF) to the available supply, biocapacity (BC) $[25,26]$. The EF is the area of ecologically productive land needed to maintain a population's consumption patterns and absorb its wastes with the prevailing technology [27-31].

The assumption of the EF tool is that all resources consumed by humanity can be traced to an area of land, in global hectares (gha), on the earth's surface. The EF tool captures natural resource flow and clearly reveals where there are ecological deficits and reserves [29]. This is done through the calculation of the EF and BC of each land use category. These disaggregated calculations are then condensed into a final consumption (EF) and supply (BC). A comparison between the $\mathrm{EF}$ and the $\mathrm{BC}$ determines the environmental sustainability status of the specific land use type or the overall area. A BC larger than EF gives an ecological reserve signifying a sustainable environment. Conversely, a BC less than EF give an ecological deficit, signifying an unsustainable environment.

Pursuant to the foregoing, four land use types: cropland, grazing land, forests for timber and firewood, and built up land [25, 26, 29] are considered in this paper. Each land use type has a supply side (BC) computed using formula 1 and demand side calculated by employing formula 2 [25, 32].

$$
\boldsymbol{B C}=\boldsymbol{A} * \boldsymbol{Y F} * \boldsymbol{E Q F}
$$

where

$\mathrm{A}=$ the area available for a given land use type,

YF and EQF are yield factor and equivalence factor, respectively, for the land use type in question. 


$$
E F=\frac{P}{Y_{D}} * E Q F
$$

where

$\mathrm{EF}=$ Ecological Footprint

$\mathrm{P}=$ the amount of a product harvested or waste emitted

$\mathrm{YD}=$ district average yield $\left(\mathrm{t}\right.$ wha $\left.{ }^{-1} \mathrm{yr}^{-1}\right)$

$\mathrm{EQF}=$ equivalence factor for the land use type in question.

It is important to emphasise that the EF tool traces resource flows. Therefore weather the land used to produce goods falls within the physical boundary of the consumer or not, the ecological demand is placed under the consumer. The tool computes land used to produce goods within the resettled areas. It also calculates the land area embodied in the goods imported into or exported out of the district. This culminates in EF of Production $\left(\mathrm{EF}_{\mathrm{P}}\right)$, Imports $\left(\mathrm{EF}_{\mathrm{I}}\right)$ and Exports $\left(\mathrm{EF}_{\mathrm{E}}\right)$ to cater for the ecological land used in the production of goods within the resettled area, land as well as embodied in imported goods as well as exported goods, respectively. To get the actual ecological land consumed in the district, the EF of consumption $\left(\mathrm{EF}_{\mathrm{C}}\right)$, production and imports are added together and exports subtracted.

Both primary and secondary statistics were collected for the EF tool to determine environmental sustainability. Primary data was collected through the administration of questionnaires to sampled households. Government offices provided secondary data across all the four land use classes. The EF tool uses a year as a temporal unit of measurement. Therefore, all the data collected for this study was for the year 2010 as ten years are long enough for human activity to have a measurable influence on the ecosystem.

Consequently a sample size of 150 households represented the 5167 households in the resettlement areas (95\% at 7.89 confidence). The sample was taken from both new and old resettlement areas as shown in Table 1 . The household figures are as at April 2010. The household interviews solicited for biophysical information from the respondents. Statistics such as area (ha) put under different land uses, production from different land uses, grazing resources, livestock resources and crop production were gathered.

Key informant interviews with officials from the Ministry of Lands and Rural Resettlement, AGRITEX, Veterinary Services as well as the District Administrator provided secondary statistics. Both primary and secondary data were then captured into the Microsoft Excel worksheets for computation of the environmental sustainability of the resettled areas. Following the application of the above formulae, $\mathrm{BC}$ and $\mathrm{EF}$ of the old and new resettlement were compared to find the ecological reserve (or deficit as the case may be). The following section deals with the results and their implications on environmental sustainability. In addition the section reveals whether the critics of the FTLRP were correct or off the mark. 
Table 1: $\quad$ The sample size.

\begin{tabular}{|l|l|c|c|c|}
\hline \multicolumn{2}{|l|}{ Resettlement type } & Old Resettlement & New Resettlement & Totals \\
\hline \multirow{3}{*}{ Households } & Number & 861 & 4306 & 5167 \\
\cline { 2 - 5 } & Per cent & 15.7 & 84.3 & 100 \\
\hline Sample size (households) & $\mathbf{2 4}$ & $\mathbf{1 2 6}$ & $\mathbf{1 5 0}$ \\
\hline
\end{tabular}

\section{Results and discussion}

The results presented here follow the elaborate calculation outlined above. Both old and new resettlement areas reveal an ecological reserve. However, it is important to delve into the individual land uses to shed more light into the environmental sustainability case at hand. Built up land cannot practically produce an ecological deficit as construction is done on land physically available in the resettled areas. As such no attention will be directed at the built up land footprint.

While it is noted that land reform has increased household crop production and improved livelihoods [33, 34], and income [21, 35] the cropland and grazing land EF should not be misconstrued to be referring to that. The EF is concerned with the degradation of once productive land. The Footprint refers to the environment's regenerative capacity exploited in the production of the said crops and livestock.

Environmental sustainability is concerned with maintenance of the ability of the ecological environment to continue providing that capacity indefinitely. The maintenance of ecological sustainability will ensure that resettled farmers will not find themselves living in a land base with ever decreasing biocapacity. Thus, in terms of cropland use, therefore, the population is living unsustainably and this has a negative impact on food security in the future.

Interestingly, both old and new resettlement areas show an ecological deficit as shown in tables 1 and 2. This supports the observation by ZERO [4] that environmental management has always been poor in the resettled areas of Zimbabwe. Worth noting is that many households have extended their arable land in the hope of increasing production. This could be the most plausible explanation for the ecological deficit. Chirumanzu is in agro ecological region III where crop production has to be under irrigation. Rain-fed subsistence farming by the resettled farmers does not produce satisfactory crops.

Table 2: Chirumanzu District Old Resettlement Ecological Footprint Account.

\begin{tabular}{|l|c|c|c|c|c|c|}
\hline Demand Type & $\mathbf{E F}_{\mathbf{P}}$ & $\mathbf{E F}_{\mathbf{I}}$ & $\mathbf{E F}_{\mathbf{E}}$ & $\mathbf{E F}_{\mathbf{C}}$ & Biocap & BC-EF $_{\mathbf{C}}$ \\
\hline \multicolumn{1}{|c}{$[-]$} & {$[\mathrm{gha}]$} & {$[\mathrm{gha}]$} & [gha] & [gha] & [gha] & [gha] \\
\hline Cropland & 54358.39 & 1329.59 & 1847.61 & 53840.36 & 11007.64 & -42832.72 \\
\hline Grazing Land & 1367.18 & 391.52 & 418.87 & 1339.83 & 190073.52 & 188733.69 \\
\hline Forest Land & 314.36 & 0.00 & 0.00 & 314.36 & 2408.33 & 2093.97 \\
\hline Built up Land & 13994.23 & - & - & 13994.23 & 15554.04 & 1559.82 \\
\hline Total & $\mathbf{7 0 0 3 4 . 1 5}$ & $\mathbf{3 8 2 3 . 3 2}$ & $\mathbf{4 5 1 5 . 5 4}$ & $\mathbf{6 9 3 4 1 . 9 3}$ & $\mathbf{2 1 9 0 4 3 . 5 3}$ & $\mathbf{1 4 9 7 0 1 . 6 0}$ \\
\hline
\end{tabular}


Be that as it may, an examination of the grazing land footprint can shed more light on the cropland footprint. The household interviews revealed that only $35 \%$ of the sampled households own some form of livestock. Out of that $31 \%$ own less than 10 livestock species. The dominant livestock species are fowl and goats, which use very little biocapacity. This can be argued to have contributed to the large ecological reserve.

Additionally, the government demands that beneficiaries in both new and old resettlement take effective occupation' of the allocated land. Effective occupation is personified by activities on the land. Therefore, the beneficiaries without livestock resort to crop cultivation and illegal arable land extension as a sign of effective occupation. Therefore this eats into the cropland biocapacity while leaving out a large ecological reserve in the grazing land use. Consequently, the grazing land ecological reserve can be termed livestock limited environmental sustainability.

Table 3: Chirumanzu District New Resettlement Ecological Footprint Account.

\begin{tabular}{|c|c|c|c|c|c|c|}
\hline Demand Type & $\mathbf{E F}_{\mathrm{P}}$ & $\mathbf{E F}_{\mathrm{I}}$ & $\mathbf{E F}_{\mathrm{E}}$ & $\mathbf{E F}_{\mathrm{C}}$ & Biocap & BC-EF $F_{C}$ \\
\hline$[-]$ & [gha] & [gha] & [gha] & [gha] & [gha] & [gha] \\
\hline Cropland & 72889.53 & 1329.59 & 2891.93 & 71327.18 & 59104.71 & -12222.47 \\
\hline Grazing Land & 16121.69 & 2493.73 & 2667.93 & 15947.49 & 190073.52 & 174126.02 \\
\hline Forest Land & 1966.48 & 0.00 & 0.00 & 1966.48 & 2408.33 & 441.86 \\
\hline Built up Land & 1527.24 & - & - & 1527.24 & 15554.04 & 14026.80 \\
\hline Total & 92504.94 & 3823.32 & 5559.86 & 90768.39 & 267140.61 & 176372.21 \\
\hline
\end{tabular}

The EF tool traces resource flows. A comparison of the grazing land imports and exports reveals that both the old and the new resettlements export more grazing land than they import. This exported biocapacity is considered under the importing areas. Such a scenario contributes to a larger ecological reserve in the grazing land use. The large grazing land ecological reserve contributes significantly to the overall ecological reserve revealing the overall environmental sustainability of the resettled area.

A further examination of the results also shows a similar trend between the newly resettled areas and the old ones. Both have an ecological deficit in cropland use and a large ecological reserve in grazing land use. It can be argued therefore, that, the new resettlements are a continuation of the old resettlement system in as far as environmental resource consumption is concerned. At the end both resettlement schemes depict a livestock limited environmental sustainability situation.

\section{Conclusion}

Livelihoods, crop production and household income have improved and order was never lost in the new era of resettlement [21, 34]. This paper has revealed that there is a generally environmentally sustainable situation prevailing in both the old and the new resettlement areas. The introduction of the FTLRP was not 
as detrimental to the environment as the popular view puts it. It is concluded that adopting the FTLRP did not result in the environmental sustainability being compromised. Rather environmental sustainability that prevailed in the old resettlement areas was retained.

\section{References}

[1] Chitsike, F., A Critical Analysis of the Land Reform Programme in Zimbabwe, Paper presented at the 2nd FIG Regional Conference, Marrakech, Morocco, December 2-5, 2003.

[2] Moyo, S., Land Policy, Poverty Reduction and Public Action in Zimbabwe Institute of Social Studies (ISS)/ UNDP Land, Poverty and Public Action Policy Paper No. 11, 2005.

[3] Mushimbo, C., Land Reform in Post-Independence Zimbabwe: A Case of Britain's Neo-Colonial Intransigence? Master of Arts Thesis, Graduate College of Bowling Green State University, 2005.

[4] Zimbabwe Environmental Research Organization (ZERO), Untitled, ZERO official website, 2005.

[5] Musyoki, A., Land Reform and the Alleviation of Poverty: towards Sustainable Rural Development, Inaugural Professorial address presented at University of Venda, 19 May1999.

[6] Mohamed-Katerere, J., Legal and Policy Studies for Shared Forest Management. Harare: Report Produced For Forestry Commission/ DFID Shared Forest Management Project, 2000.

[7] Moyo, S., The Land Question in Zimbabwe, Harare: Sapes Trust, 1995.

[8] Zimbabwe Farmers Union (Z. F. U.), Resettlement Programme in Zimbabwe: Options for the Future, Unpublished Conference Report, 1995.

[9] Clover, J., and Eriksen, S., The effects of land tenure change on sustainability: human security and environmental change in southern African savannahs. Journal of Environmental Science and Policy, 12 pp. 52-70, 2009.

[10] Land Reform Task Force, Inception Phase Framework Plan: 1999-2000, Harare: Government Printer, 1999.

[11] Chiremba, S., and Masters, W., The Experience of Resettled Farmers in Zimbabwe, African Studies Quarterly 7, no. 2\&3: [online] viewed 15 June 2010 URL: http://web.africa.ufl.edu/asq/v7/v7i2a5.htm.

[12] Muyengwa, S., and Sango, D., Decentralizing Land Reform: Lessons Drawn from Zimbabwe, Harare: Centre for Applied Social Science, University of Zimbabwe, 2008.

[13] Manjengwa, J., Natural resource management and land reform in Southern Africa, Harare: Centre for Applied Social Sciences, University of Zimbabwe, 2006.

[14] Manjengwa, J., Environment and Development issues in Zimbabwe, since 2000 and beyond, Harare: Centre for Applied Social Sciences, University of Zimbabwe, 2009. 
[15] Murombedzi, J. C., Environment and sustainable development in Zimbabwe, Harare: International Union for the Conservation of Nature (IUCN), 2004.

[16] ZANU (PF), Report by The Chairman Of National Land Acquisition Hon. J. W. Msika (MP) at ZANU (PF) Congress 15/12/2000. Unpublished.

[17] Harts-Broekhuis, A., and Huisman, H., Resettlement revisited: land reform results in resource-poor regions in Zimbabwe, Geoforum, 32 (3) pp. 285298, 2001.

[18] Mukwada, G., Unlocking Resources: The Impact of Land Reform on Sustainability of Forest and Woodland Resources and Rural Livelihoods The Case of Mufurudzi Resettlement Scheme (Zimbabwe), Ph.D. Thesis, Wits University, South Africa, 2007.

[19] Sikor, T. and Muller, D., The Limits of State-Led Land Reform: An Introduction, USA: Elsevier Ltd, 2008.

[20] Ministry of Lands, Land Reform and Resettlement (Government of Zimbabwe), Land Reform and Resettlement Program Revised Phase II, Harare: Ministry of Lands, Agriculture and Rural Resettlement, 2004.

[21] Chaumba, J., Scoones, I. and Wolmer, W., From Jambanja to Planning: The Reassertion of Technocracy in Land Reform in South-eastern Zimbabwe, The Journal of Modern African Studies, 41(4), pp. 533-554, 2003.

[22] Monfreda, C., Wackernagel, M., and Deumling, D., Establishing national natural capital accounts based on detailed ecological footprint and biological capacity accounts, Land Use Policy, 21, pp. 231-246, 2004.

[23] Lewan, L., and Simmons, C., (eds). A short Primer on the Ecological Footprint, London: Earthscan Publications, 2001.

[24] Weidmann, T., and Lenzen, M., On the conversion between local and global hectares in ecological footprint analysis, Ecological Economics, 60, pp. 673-677, 2007.

[25] Ewing, B., Reed, A., Rizk, S.M., Galli, A., Wackernagel, M. and Kitzes, J., Calculation Methodology for National Footprint Accounts, 2008 Edition, Oakland: Global Footprint Network, 2008.

[26] Ewing, B., Moore, D., Goldfinger, S., Oursler, A., Reed, A., and Wackernagel, M., The Ecological Footprint Atlas 2010, Oakland: Global Footprint Network, 2010.

[27] Wackernagel, M., and Rees, W., Our Ecological Footprint. Reducing Human Impact on the Earth, Gabriola Island, BC: New Society Publishers, 1996.

[28] Wackernagel, M., and Rees, W. E., Perceptual and structural barriers to investing in natural capital: economics from an ecological footprint perspective, Ecological Economics, 20 pp. 3-20, 1997.

[29] Wackernagel, M., Schulz N. B., Deumling, D., Callejas Linares, A., Jenkins, M., Kapos, V., Monfreda, C., Loh, J., Myers, N., Norgaard, R. and Randers, J., Tracking the ecological overshoot of the human economy, USA: National Academy of Science, 2002.

[30] Moldan, B., Hak, T., Kovanda, J., Havranek, M. and Kuskova, P., "Composite Indicators of Environmental Sustainability." Statistics, 
Knowledge and Policy - OECD World Forum on Key Indicators, Palermo 10-13 November 2004.

[31] Mayer, A. L., Strengths and weaknesses of common sustainability indices for multidimensional systems, Environment International, 34. pp. 277-291, 2008.

[32] Kitzes, J., Wackernagel, M., Loh, J., Peller, A., Goldfinger, S., Cheng, D., Tea, K., Shrink and share: humanity's present and future ecological footprint, Philosophical Transactions of the Royal Society B 363, pp. 467475, 2008.

[33] Deininger, K., and May, J., Can there be growth with equity: an initial assessment of land reform in South Africa, 1, Policy, Research working paper, no. WPS 2451, 2000.

[34] Scoones, I., Marongwe, N., Mavedzenge, B., Murimbarimba, F., Mahenehene, J., and Sukune, C., Zimbabwe's Land reform: myths and Realities, Harare: Weaver Press, 2010.

[35] Zikhali, P., Fast Track Land Reform, Tenure Security, and Investments in Zimbabwe, Environment for Development Discussion Paper Series, June, 2008. 